https://nv.nltu.edu.ua

https://doi.org/10.36930/40310103

Article received 21.12.2020 p.

Article accepted 04.02.2021 p.

${ }^{2}$ Національний лісотехнічний університет Украйни, м. Львів, Україна

\title{
АЛЕЛОПАТИЧНА АКТИВНІСТЬ TRIFOLIUM REPENS L. TA T. RUBENS L. (FABACEAE) В УМОВАХ НАЦІОНАЛЬНОГО БОТАНІЧНОГО САДУ ІМЕНІ М. М. ГРИШКА НАН УКРАЇНИ
}

На сьогодні досягнення алелопатії дають змогу досліджувати характер хімічної взаємодії між рослинами як у природних фітоценозах, так і у вирощуванні рослин культурної флори. Ця взаємодія полягає у пригніченні або стимуляції проростання насіння, росту та розвитку передусім особин одного виду та довколишніх видів цього фітоценозу. Алелопатична активність $\epsilon$ важливою ознакою для конкуренції та виживання виду на певній території. Біологічно активні сполуки, що $є$ засобом алелопатичної конкуренції, можуть бути виділені у повітря, змиті з поверхні листка на поверхню грунту, виділені кореневою системою безпосередньо в грунт. Кореневі виділення рослин призводять до грунтовтоми, яка є комплексною і ключовою проблемою для сільського господарства, та вимагає правильного чергування та поєднання культур на посівних площах та обов'язкового дотримання режиму відпочинку грунтів. Здійснено літературний скринінг вітчизняних і закордонних джерел, які роблять висновок про високу алелопатичну активність рослин роду Trifolium, яка отримала назву "конюшиновтома". У процесі досліджень зроблено висновок, що під час тривалого росту на одному місці рослини T. rubens i T. repens проявляють алелопатичну активність відносно довколишніх рослин. Алелопатичну активність виділень кореневої системи у ризосферному грунті та екстрактів надземної частини рослин T. rubens i T. repens встановлювали за методикою А. М. Гродзінського (1973). Для тестування використано однодобові проростки тест-рослин амаранту Amarantus paniculatus. Встановлено, що алелопатична активність ризосферного грунту рослин роду Trifolium перебуває у динаміці, внаслідок накопичення виділень (колінів) кореневої системи рослин, із найвищими показниками у кінці вегетаційного періоду. Зроблено висновок, що рослини T. rubens, як кореневі їх виділення, так і екстракти надземних органів, є сильнішими інгібіторами, ніж $T$. repens. Зроблено узагальнення, що, незалежно від виду рослин роду Trifolium та фази вегетації, екстракти за концентрації 1:10 мають найбільшу інгібуючу активність, за концентрації 1:50 - мають середні показники, за концентрації 1:100 - найменше інгібування. Встановлено закономірність, що зі збільшенням концентрацій розчинів рослин роду Trifolium їх інгібуюча алелопатична активність підвищується. Найсильнішу інгібуючу дію $(7,22$ \%) зафіксовано у рослин $T$. rubens наприкінці вегетації, найсильнішу стимулятивну дію $(113,64 \%)$ - у рослин цього самого виду у фазу цвітіння. Актуальним для майбутніх досліджень залишається встановлення якісного та кількісного вмісту колінів ризосферного грунту та біологічно активних речовин надземної частини рослин роду Trifolium.

Ключові слова: коліни; ризосферний грунт; екстракти; тест-рослини; інгібування; стимулювання; стійкість.

\section{Вступ}

У процесі тривалого росту рослин, прикріпленими нерухомо на одному і тому самому місці, у довкільному середовищі відбувається накопичення алелопатично активних речовин, які можуть бути токсичними як для довколишньої флори, так і для самих рослин, що їх продукують (аутоінтоксикація). У прикореневому грунті впродовж вегетаційного періоду фіксують різні за походженням та будовою коліни або біологічно активні речовини, хімічні інгібітори, які є результатом метаболіз- му вищих рослин та мікроорганізмів, виділяються в довкільне середовище і впливають на ріст інших рослин, селекціонують мікрофлору $[22,27]$.

Процес накопичення призводить до максимальної алелопатичної активності колінів у кінці вегетації та може проявлятися як у пригніченні, так і в стимулюванні угруповань рослин у фітоценозах. Питання грунтовтоми та хімічної взаємодії рослин є комплексною і ключовою проблемою як для сільського господарства, оскільки зобов'язує враховувати чергування культур у сівозміні та влаштування відпочинку грунту, так і у фіто-

\section{Інформація про авторів:}

Левчик Наталія Яківна, канд. біол. наук, ст. наук. співробітник, відділ культурної флори. Email: levchyk.n@ukr.net; https://orcid.org/0000-0001-8668-8763

Гнатюк Алла Миколаївна, канд. біол. наук, ст. наук. співробітник, відділ природної флори. Email: colchicum@i.ua; https://orcid.org/0000-0001-5001-971X

Любінська Алла Василівна, пров. інженер, відділ культурної флори. Email: alla@ukr.net; https://orcid.org/0000-0002-1873-8252

Горбенко Наталія Євгенівна, канд. с.-г. наук, доцент, кафедра ботаніки, деревинознавства та недеревних ресурсів лісу. Email: nata.horbenko@gmail.com; https://orcid.org/0000-0002-6053-6582

Цитування за Дсту: Левчик Н. Я., Гнатюк А. М., Любінська А. В., Горбенко Н. Є. Алелопатична активність Trifolium repens L. та T. rubens I. (Fabaceae) в умовах національного ботанічного саду імені М. М. Гришка НАН України. Науковий вісник НлтУ України. 2021, т. 31, № 1. С. 20-25.

Citation APA: Levchyk, N. Ya., Gnatiuk, A. M., Liubinska, A. V., \& Horbenko, N. Ye. (2021). The allelopathic activity of Trifolium repens L. and T. rubens L. (Fabaceae) in the conditions of the M. M. Gryshko National Botanical Garden of the National Academy of Sciences of Ukraine. Scientific Bulletin of UNFU, 31(1), 20-25. https://doi.org/10.36930/40310103 
ценології - для оцінювання конкурентоспроможності рослин у природних та культурних фітоценозах.

Бобові Leguminosae (= Fabaceae) - третя за величиною родина квіткових рослин за кількістю видів, екологічною різноманітністю та поширенням, налічує близько 300 видів. Окрім цього, є одним із важливих об'єктів інтродукції, оскільки відіграє провідну роль у формуванні природних ценозів та агроценозів [4]. Рід конюшина, Trifolium L. - один із найбільших у родині, поширений на всіх континентах, окрім Австралії [2, 9, 16, 20]. У флорі України описано 38 видів [18], але лише два з них занесено до Червоної книги України (2009).

Серед дикорослих видів вітчизняної флори необхідно виділити $T$. rubens L, конюшину червонувату, центральноєвропейсько-субсередземноморський вид, що зрідка трапляється у правобережній частині України (Закарпаття та Волино-Поділля). Характеризується стенотопною еколого-ценотичною амплітудою і $\epsilon$ чутливим до надмірного впливу антропогенних факторів, погано відновлюється. За останні десятиліття кількість локалітетів і чисельність популяцій істотно скоротилися [7]. Рослини трапляються невеликими куртинами чи поодиноко, приурочені до суходільних луків, лучних степів, узлісь, чагарників; вид характерний для ксеромезофітних угруповань кл. Festuco-Brometea (союз CirsioBrachypodion pinnati) та Trifolio-Geranietea [19]. У НБС у культурі на колекційних ділянках T. rubens вирощують як перспективну кормову, медоносну та декоративну культуру.

T. repens (конюшина повзуча) - багаторічна рослина iз сланкими пагонами, які укорінюються по вузлах. Листки довгочерешкові, трійчасті; листочки оберненояйцеподібні, дрібнозубчасті. Квітки білі. С добрим медоносом. Вид поширений у Свразії, Пн. Африці та Пн. Америці; широко культивується. Прекрасна рослина для пасовищ, оскільки добре витримує витоптування. В Україні часто росте на полях, луках, вздовж доріг (окрім високогір'я Карпат) [2, 3]. У ботанічному саду рослини ростуть на газонах, вздовж доріг і стежок.

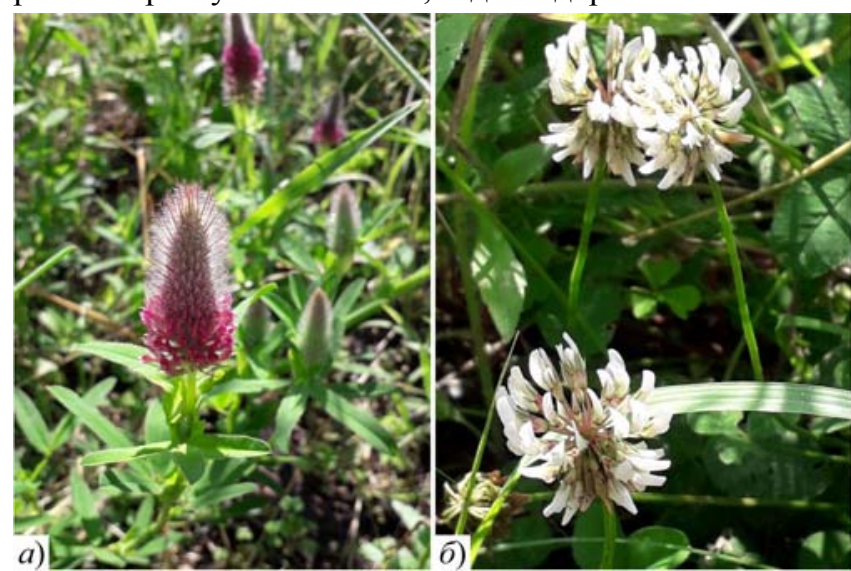

Рис. 1. Рослини: a) T. rubens; б) T. repens на ділянках відділу природної флори НБС (фото Гнатюк А. М.)

Загалом бобові мають високий вміст біологічно активних речовин, зокрема флавоноїдів та білку. Тому переважна більшість видів родини - важливі сільськогосподарські, високобілкові кормові та лікарські рослини, але використовуються переважно як кормові культури. Завдяки наявності азотфіксуючих бульбочкових бактерій бобові підвищують родючість грунту, збагачуючи його легкозасвоюваною формою азоту, тому є перспек- тивними для залуження еродованих земель, відвалів шахт і схилів [3, 19, 28].

На сьогодні, на жаль, питання стійкості та алелопатичної взаємодії рослин роду Trifolium у вітчизняній та світовій науці досліджено недостатньо, а результати інколи мають діаметральний характер. Внаслідок цього напрямок дослідження рослин видів роду Trifolium, особливостей їх біології, можливостей алелопатичної взаємодії, впливу на процеси грунтовтоми та аутоінтоксикації, потенціалу стійкості та конкурентоспроможності із іншими видами культурної флори вважаємо актуальним і перспективним.

Об'єкт дослідження - рослини двох видів роду Trifolium: T. rubens L. i T. repens L.

Предмет дослідження - методи і засоби дослідження алелопатичної активності рослин для оцінювання адаптивного потенціалу в умовах зміни погодно-кліматичних умов та сівозмін під час вирощування в культурних фітоценозах.

Мета роботи - встановити алелопатичний потенціал рослин двох видів роду Trifolium: T. rubens L. і T. repens L.; оцінити можливості цих видів до конкуренції в умовах глобальної зміни погодно-кліматичних умов під час росту у змішаних посадках культурної та природної флори.

Для досягнення зазначеної мети визначено такі основні завдання дослідження: визначити та оцінити характер і силу алелопатичного впливу ризосферного грунту та екстрактів із надземної маси рослин $T$. rubens L. i T. repens L.

Наукова новизна отриманих результатів дослідження - вперше здійснено порівняльну характеристику алелопатичного потенціалу рослин двох видів роду Trifolium: T. rubens L. i T. repens L., що стане теоретичним підгрунтям для ефективного, економічного та безпечного рослинництва.

Практична значущість результатів дослідження полягає у використанні особливостей взаємодії рослин у культурних фітоценозах під час планування посівів i сивозмін кормових, овочевих і технічних культур в аграрному виробництві.

Аналіз останніх досліджень та публікацій. Дослідженню алелопатичної взаємодії рослин роду Trifolium приділяли увагу А. М. Гродзінський (1973), Tamura (1969), Chang (1969), Baeumer, Lochow, (1961), зробивши загальний висновок, що найбільш відома грунтовтома саме під час вирощування конюшини червоної Trifolium pratense L., та ввели в обіг термін "конюшиновтома". У листках та стеблах цих рослин виявлено декілька фізіологічно активних речовин: нові ізофлаваноїди глюкозид біоханіна A, або 7-D- $\beta$-глюкозил-5,7-дигідроокси-4'-метокси-ізофлавон, і його 5-малоновий ефір, а також трифоліризин, ононін, дайдзеїн і його 7-глюкозид, формононетин, геністеїн і біоханін А. Усі ці сполуки пригнічують проростання насіння конюшини в концентраціях близько 30-1000 мг/л [6, 26]. Цікаво, що насіння конюшини червоної виявилося значно чутливішим до цих флавоноїдів, ніж насіння інших видів конюшини та салату-латуку, що свідчить про високий рівень аутоінтоксикації [17]. Злакові, зокрема рис, майже не пригнічуються інгібіторами Trifolium, що підтверджує спостереження нечутливості злаків до конюшиновтоми [6]. 
У грунті, "стомленому" Trifolium pratense L., містяться інгібітори росту, однак не ізофлавоноїди, а, як зроблено припущення, фенольні кислоти, що виникли 3 них. Серед них було ідентифіковано n-метабензойну, саліцилову та n-гідрооксибензойну кислоти. Отже, конюшиновтома, на думку японських вчених, пов'язана із нагромадженням у грунті фізіологічно активних речовин [26].

Ще А. М. Гродзінський (1973) зазначав, що серед водорозчинних сполук, які адсорбуються грунтом, для алелопатії найбільше значення мають фенольні кислоти типу n-кумарової, гідроксикоричної, ванілінової, ферулової, гідрооксибензойної тощо [14].

Окрім цього, не можна не врахувати те, що рослини роду Trifolium $\epsilon$ азотфіксуючими видами. Внаслідок фіксації атмосферного азоту вони здатні сприяти розвитку сусідів у змішаних посівах або у фітоценозах, що, відповідно, не вигідно для них самих. Проте відомі випадки пригнічення бобовими росту та розвитку партнерів, і це $\epsilon$ підтвердженням того, що взаємозв'язки між рослинами надзвичайно складні та багатогранні. Теоретично бобові мають бути особливо алелопатично стійкими. У процесі еволюції у них виникла специфічна здатність протистояти надмірному росту сусідів за допомогою алелопатичного механізму [14].

Зокрема, дослідження Гранта та Селланса (1973) показали високу алелопатичну активність рослин Trifolium rubens. Виявлено, що екстракти із надземних частин конюшини повзучої або білої Trifolium repens пригнічували проростання всіх дослідних рослин, окрім тимофіївки та лядвенцю. Серед екстрактів бобових найменш токсичними були екстракти, отримані із червоної конюшини Trifolium pratense [22]. Загалом екстракти із надземних частин були більш токсичними, ніж екстракти коренів.

Однак результати діаметрально протилежних досліджень виявили, що кореневі виділення рослин-інгібіторів (представників різнотрав'я Ambrosia psilostachya, Euphorbia supuna, Helianthus annuиs та злакових культур Aristida oligantha, Bromus japonicus, Digitaria sanguinalis) істотно впливають на утворення бульбочок у рослин Trifolium repens [22].

Процес алелопатії - це комплексна взаємодія, в якій задіяні, окрім вищих рослин, бактерії та мікроорганізми. Наприклад, внаслідок досліджень Хеттінга і Лоува (1969) було виділено із поверхні коренів конюшини повзучої Trifolium repens штам Pseudomonas (позначений як W78), який пригнічував розвиток інокульованої та неінокульованої конюшини. Було висловлено гіпотезу, що інгібування Pseudomonas пов'язано із виділенням бактерією токсину 2,4-диацетилфлороглюцину [13]. Окрім цього, у ризосфері конюшини червоної Trifolium pratense виявлено мікроорганізми, які пригнічують ріст ризобіуму рослин [22].

У дослідженнях Mahdieh Ebrahimi та співавторів (2017) виявлено, що процес проростання насіння, ріст та поглинання поживних речовин Peganum harmala L. були порушені інгібуючим ефектом екстракту Trifolium alexandrium. Однак менші концентрації екстракту конюшини показали позитивний вплив на ріст рослини Peganum harmala. Результати різних досліджень показали, що такі сполуки, як фенольна та сантонова кислоти, можуть бути введені як інгібуючі фактори вивчених характеристик T. alexandrium. Окрім цього, екстракт $T$. alexandrium істотно впливав на поглинання $\mathrm{N}, \mathrm{P}, \mathrm{K}, \mathrm{Zn}$ та $\mathrm{Mn}[8]$.

У дослідженнях Kruse Marianne та ін. (2000) зазначено про широкий спектр культур, які здійснюють пригнічувальну дію на бур'яни, можливо, опосередковану виділенням алохімічних речовин, серед яких вказана конюшина (Trifolium spp.) [17].

Через низьку стійкість, виробництво зернобобових культур у Середземномор'ї $є$ під загрозою з боку голопаразитної рослини Orobanche crenata. У роботі М. Fernandez-Aparicio (2010) бобову культуру Конюшини олександрійської (Trifolium alexandrinum), що є важливою з економічної точки зору фуражною бобовою культурою у Східному Середземномор'ї та тропічних районах, запропоновано використовувати як відповідну пастку для регулювання O. crenata. Внаслідок досліджень запропоновано використовувати Trifolium alexandrinum для щільних посівів (два і більше на одній площі) 3 іншими зернобобовими культурами. Описано iї алелопатичну активність проти проростання насіння O. crenata. Результати підтверджуються трирічними польовими експериментами в Сгипті зі значним зменшенням кількості інфекції O. crenata на квасолі та гороху при спільному вирощуванні з Trifolium alexandrinum. Експерименти з міні-ризотроном також продемонстрували зменшення інфекції $O$. crenata на гороху, сочевиці та чині посівній [10].

У роботі Andy J. Perez (2015) зазначено, що з надземних частин Trifolium argutum Sol (конюшина гострозуба) було виділено чотири тритерпеноїдні сапоніни (14). Їх структури вивчено за допомогою всебічного спектроскопічного аналізу, включаючи 1D та 2D NMR техніки, мас-спектрометрію та хімічні методи. Два 3 них нові сполуки, що характеризуються як 3-O- [ $\alpha-1-$ рамнопіранозил- $(1 \rightarrow 2)$ - $\beta$-d-галактопіранозил- $(1 \rightarrow 2)$ - $\beta$-dглюкуронопіранозил] -3 $\beta, 24$-дигідроксіолеїн -12-ен-22оксо-29-оїнова кислота (1) та 3-O- [ $\beta$-d-галактопіранозил- $(1 \rightarrow 2)$ - $\beta$-d-глюкуронопіранозил] -3 $\beta, 24$-дигідроксиолеан-12-ен -22-оксо-29-оїнова кислота (2). Вперше повідомляється про появу серед видів Trifolium $3 \beta$, 24-дигідроксіолеан-12-ен-22-оксо-29-оєвої кислоти (мелілотигенін) у природній формі у вигляді тритерпеноїдного аглікону. Фітотоксичність сполук оцінювали на чотирьох стандартних цільових видах (STS) за концентрації від 1 до 333 мкМоля. Сполука 1 була найактивнішою, демонструючи більш ніж 60 \% пригнічення росту кореня Lactuca sativa за вищої дози, з IC $_{50}(254,1$ мкМоль) нижчим, ніж у Logran ${ }^{\circ}(492,6$ мкМоль), комерційного гербіциду, що використовували як позитивний контроль. Зв'язок між структурою та активністю вказувало на те, що як аглікони, так і глікозидні частини можуть впливати на фітотоксичність сапонінів [21].

У роботі С. К. Sandra (2011) вперше вивчено виділення флавоноїдів як з вирощеної у польових умовах білої конюшини Trifolium repens L., так і включених у грунт флавоноїдів рослин, які аналізували методом рідинної хроматографії і тандемної мас-спектрометрії (LC-MS/MS). Домінантними флавоноїдними агліконами були формононетин, медикарпін та кемпферол. Включені у грунт рослини конюшини білої генерували високі концентрації глікозидів кемпферол-Rha-Xyl-Galand та кверцетин-Xyl-Gal. Значна кількість кемпферолу зберігалася у грунті впродовж декількох днів, тоді як інші сполуки розкладалися швидше. Ці сполуки потріб- 
но враховувати у майбутніх дослідженнях грунтовтоми, алелопатичної активності та можливих екологічних ризиків від тривалого вирощування конюшини [23].

Цікаві дослідження Н. О. Симагіної (2013) повідомляють про алелопатичний вплив виділень надземної частини деревних рослин Tilia cordata Mill, Fagus orientalis Lypsky, Platanus orientalis L., Catalpa bignonioides Walt. на морфометричні параметри Trifolium repens L., що характеризують його життєву стійкість на ранніх етапах онтогенезу. За результатами експериментів виявлено особливості впливу фітотоксичних сполук надземних органів деревних рослин на трав'яні. Визначено алелопатичний поріг чутливості тест-об'єкта Trifolium repens [25].

Матеріали та методи дослідження. Для роботи обрали два види рослин роду Trifolium: T. rubens i T. repens колекції відділу природної флори Національного ботанічного саду ім. М. М. Гришка НАН України (далі НБС).

Алелопатичні властивості прикореневого грунту та екстрактів надземної маси рослин $T$. rubens i $T$. repens проводили за загальноприйнятою методикою біотестів А. М. Гродзінського (1973). Ризосферний грунт та рослинний матеріал відбирали відповідно до змін фаз вегетації: цвітіння, плодоношення, кінець вегетації. Із надземної частини рослин готували водні екстракти у концентрації 1:10, 1:50 та 1:100. Тест-об'єктом були однодобові проростки амаранту Amarantus paniculatus. Peзультати досліджень обчислювали статистично за методами варіаційної статистики [24].

\section{Результати дослідження та їх обговорення}

Важливо зазначити, що адсорбція колінів грунтом $є$ не перешкодою, а навпаки, передумовою алелопатичної ïx дії. Грунт $є$ найважливішим посередником алелопатії [14].

Згідно з отриманими результатами, прикореневий грунт рослин T.rubens істотно алелопатично активніший із гальмівним характером впливу на проростки амаранту, порівняно з $T$. repens. Істотне інгібування грунту рослинами $T$. rubens у фазі цвітіння становить $76,00 \%$, змінюється незначною дією 97,45\% у фазі плодоношення та має інгібуючу дію - до 70,73 \% на кінець вегетації. На відміну від попередньої тенденції, біологічно активні речовини грунту рослин Trifolium repens у фазі цвітіння практично не впливають на тестрослини (101,00\%), неістотно стимулюють (107,00 \%) у фазі плодоношення та відчутно інгібують $(83,46 \%)$ в кінці вегетації (рис. 2).

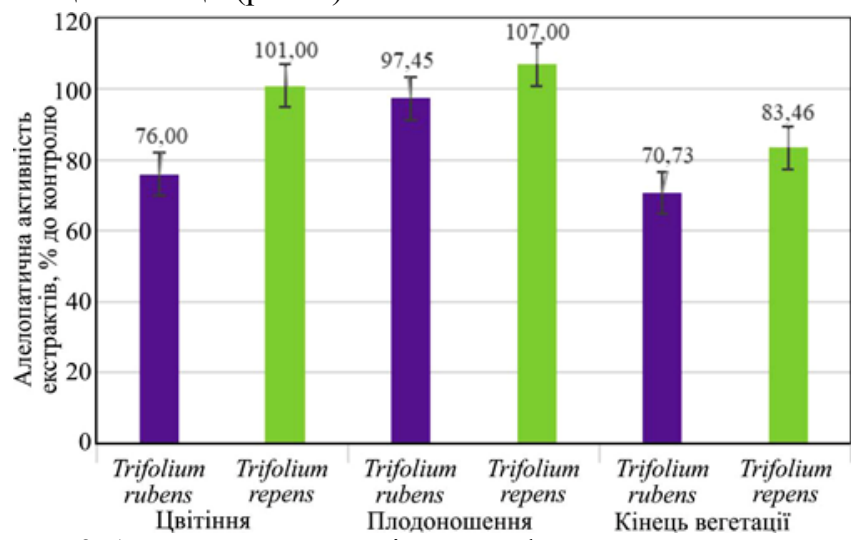

Рис. 2. Алелопатична активність ризосферного грунту рослин роду Trifolium, \% до контролю
Отже, виявлено, що дія прикореневого грунту досліджуваних видів рослин має переважно інгібуючий характер. Коліни T. rubens виявились активнішими інгібіторами, ніж у $T$. repens, оскільки їх алелопатична дія пригнічувала тест-рослини майже на $30 \%$ порівняно 3 контролем. На відміну від T. rubens, у T. repens, максимальні показники пригнічення тест-рослин не перевищували 16,54 \% порівняно 3 контролем. Відомо, що впродовж вегетаційного періоду у прикореневому грунті відбувається природне накопичення виділень кореневої системи, що відповідно і призводить до збільшення алелопатичної активності як T. rubens, так і T. repens caме на кінець вегетації рослин.

Екстракти досліджуваних рослин роду Trifolium істотно впливають на проростки амаранту, характер їхньої дії є суто інгібуючий. Виняток становить екстракт T. rubens концентрації 1:100 під час цвітіння, дія якого була стимулятивною із показниками 113,64 \% (рис. 3 ).

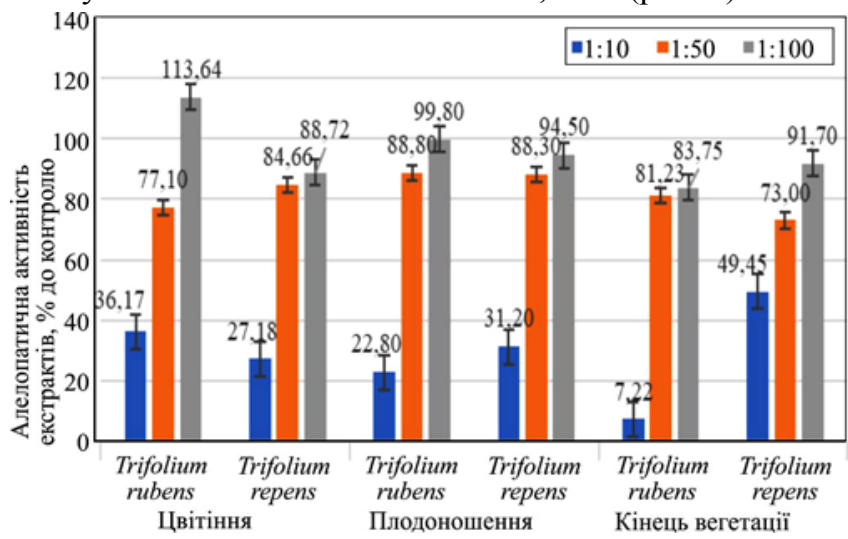

Рис. 3. Алелопатична активність екстрактів рослин роду Trifolium залежно від концентрації $(1: 10,1: 50,1: 100)$ та фаз вегетації, \% до контролю

У процесі дослідження встановлено, що сила дії екстрактів перебуває у прямій залежності від їх концентрації та від фаз вегетації рослин див. (рис. 3). Найсильніша інгібуюча дія - 7,22 \% - проявилась наприкінці вегетації у тотальному пригніченні приросту кореня проростків амаранту екстрактом $T$. rubens за умові, що розчин був у концентрації 1:10. Окрім цього, сильна інгібуюча алелопатична дія - від 22,80 до 36,17 \% - зафіксована, незалежно від виду Trifolium, за умови, що концентрація екстрактів становила 1:10. Середні показники - від 73,00 до 88,80 \% - за концентрації 1:50. I помірна інгібуюча дія - від 83,75 до 99,80 \% - зафіксована за концентрації екстракту 1:100. Отже, із збільшенням концентрації екстрактів рослин роду Trifolium їх алелопатична активність відповідно збільшується.

Існує думка, що встановлена у фазу цвітіння максимальна інгібуюча алелопатична активність екстрактів $T$. repens $(27,18 \%)$ та найбільша стимулятивна дія екстрактів T. rubens $(113,64$ \%) може бути пов'язана із фізіологічною активністю рослин у цей період. На відміну, для максимального інгібування T. rubens $(7,22 \%)$ - це кінець вегетації, що є періодом накопичення у тканинах токсичних біологічно активних сполук фенольного походження. Ці питання потребують подальшого докладнішого вивчення.

Результати нашого дослідження перегукуються із науковцями Chang, Ch., Suzuki, A., Kumai, S., \& Tamura, S. (1968), які своїми експериментами підтвердили, що причиною так званої "хвороби конюшини" $є$ алелопа- 
тична дія конюшини червоної внаслідок накопичення у грунтах інгібіторів та продуктів їхнього розпаду. Було встановлено, що ці інгібітори належать до фенольних сполук, а саме ізофлавоноїдів та споріднених сполук, які можуть бути перетворені у кислоти до або після загибелі рослин конюшини червоної [6].

Алелопатична активність фенольних компонентів у ризосферному грунті, за дослідженнями Grbović Filip, Gajić Gordana, Branković Snežana та ін. (2019), перебуває під сильним впливом кислотності $\mathrm{pH}$, вмісту С та доступного $\mathrm{P}$, а також загального вмісту $\mathrm{Cu}$ та наявного вмісту Mn та Ni в золі [12].

Sandra C. K. Carlsen та колеги встановили екологічні ризики від флавоноїдів Trifolium repens, що накопичуються у грунті. Найбільш сконцентровані флавоноїдні аглікони, виявлені в грунті, були формононетин, медикарпін, кемпферол та кверцетин [23].

Феномен алелопатії трапляється у всіх екосистемах і включає складний хімічний зв'язок між ними, як підсумували Jankowska Jolanta, Grażyna Anna Ciepiela та ін. (2009), під час дослідження впливу водної витяжки рослинних залишків Trifolium repens на повне гальмування проростання та росту коріння самої ж T. repens, що є яскравим прикладом аутоінтоксикації [15].

Дослідження плануємо продовжити, оскільки для розуміння алелопатичних взаємовідносин між рослинами та можливості керування цим процесом особливо важливого значення набуває ідентифікація фізіологічно активних речовин, які здебільшого важко встановити, оскільки в природних умовах вони перебувають не тільки у вільному, але й у зв'язаному стані, і саме в такому вигляді $\epsilon$ алелопатично активними [27]. Тому актуальним $є$ встановлення якісного та кількісного вмісту колінів ризосферного грунту та біологічно активних речовин надземної частини рослин роду Trifolium.

\section{Висновки}

На основі здійснених досліджень виявлено, що впродовж вегетаційного періоду рослин роду Trifolium у прикореневому грунті відбувається накопичення біологічно активних речовин, колінів, що надає йому алелопатичної активності із найвищим іiі рівнем на кінець вегетації рослин.

Кореневі виділення та екстракти надземної частини рослин $T$. rubens є сильнішими інгібіторами, ніж у рослин T. repens. Ці параметри можна розглядати як індикатор стійкості та конкурентоспроможності виду у культурних або природних фітоценозах.

Незалежно від виду рослин роду Trifolium та фази вегетації, найбільшою алелопатичною активністю із пригнічуючим характером дії є екстракти у концентрації 1:10, середні показники - за їх концентрації 1:50, найменша алелопатична активність - за концентрації 1:100. Із збільшенням концентрацій екстрактів рослин роду Trifolium ї інгібуюча алелопатична активність збільшується. Встановлену закономірність можна використовувати для прогнозу та планування посівів у аграрному виробництві.

Найсильнішу інгібуючу дію (7,22 \%) виявлено у рослин T. rubens наприкінці вегетації, що може свідчити про накопичення в тканинах токсичних біологічно активних сполук. Найсильнішу стимулятивну дію $(113,64 \%)$ встановлено у рослин цього самого виду у фазі цвітіння. Це свідчить про високу фізіологічну активність рослин у період їх активного росту та цвітіння.

\section{References}

1. Baeumer, K., \& Lochow, V. I. (1961). Untersuchungen uber die echte Kleemudigkeit. 3. Beobachtungen an einem FruchtfolgeVersuch. Z. Acker- und Pflanzenbau, 113, 4. [In German].

2. Bobrov, E. G. (1945). Trifolium L. In: Flora of USSR. Vol. 11. Moscow-Leningrad: Publishing AN SSSR, 189-261. [In Russian].

3. Bobrov, Ye. G. (1987). Clover - Trifolium L. In: Flora of the European part of the USSR, 6, 195-208. [In Russian].

4. Bondarchuk, O. P., \& Rakhmetov, D. B. (2016). Ontomorphogenesis of plant of the genus Astragalus L. species in conditions of introduction in the Right-Bank of Forest-Steppe of Ukraine. Plant Introduction, 70, 45-51. https://doi.org/10.5281/zenodo.235517

5. Carlsen, S. C. K., Pedersen, H. A., Spliid, N. H., \& Fomsgaard, I. S. (2012). Fate in Soil of Flavonoids Released from White Clover (Trifolium repens L.). Applied and Environmental Soil Science, 1-10. https://doi.org/10.1155/2012/743413

6. Chang, Ch., Suzuki, A., Kumai, S., \& Tamura, S. (1968). Chemical studies on "clover sickness". Part II. Biological function of isoflavonoids and their related compounds. Agricultural and Biological Chemictry, 33, 398-408. https://doi.org/10.1080/00021369.1969.10859325

7. Didukh, Ya. P. (Ed.) (2009). Trifolium rubens L. In: Red Data Book of Ukraine. Plant Kingdom, 565 p. [In Ukrainian].

8. Ebrahimi, M., Maryshany, A. R., \& Shirmohammadi, E. (2017). Allelopathy Effects of Trifolium alexandrium L. on Germination and Nutrient Uptake in Medicinal Plant Peganum harmala L. Journal of Medicinal Plants and By-products, 6(1), 71-79.

9. Ellison, N., Liston, A., Steiner, J., Williams, W., \& Taylor, N. (2006). Molecular phylogenetics of the clover genus (Trifolium Leguminosae). Molecular Phylogenetics and Evolution, 39(3), 688-705. https://doi.org/10.1016/j.ympev.2006.01.004

10. Fernández-Aparicio, M., Emeran, A. A., \& Rubiales, D. (2010). Inter-cropping with berseem clover (Trifolium alexandrinum) reduces infection by Orobanche crenata in legumes. Crop Protection, 29(8), 867-871. https://doi.org/10.1016/j.cropro.2010.03.004

11. Grant, E. A., \& Sallans, W. C. (1964). Influence of plant extracts on germination and growth of eight forage species. Grass and $\mathrm{FO}_{\mathrm{O}}$ rage Science, 19(2), 191-197.

12. Grbović, F., Gajić, G., Branković, S., Simić, Z., Ćirić, A., Rakonjac, L., Pavlović, P., \& Topuzović, M. (2019). Allelopathic potential of selected woody species growing on fly-ash deposits. Arch Biol Sci., 71(1), 83-94.

13. Hatting, M. J., \& Louw, H. A. (1969). The influence of antagonistic rhizoplane bacteria on the clover-Rhizobium symbiosis. Phytophylactica, 1, 205-208.

14. Hrodzinskiy, A. M. (1973). The fundamentals of chemical interaction of plants. Kyiv: Scientific thought, 205 p. [In Ukrainian].

15. Jankowska, J., Ciepiela, G. A., Sosnowski, J., Kolczarek, R., \& Jankowski, K. (2009). The allelopathic effect of Taraxacum officinale F. G. Wigg on the seeds germination and initial growth of $\mathrm{Lo}$ lium westerwoldicum R. Br. Acta Agrobotanica, 62(2), 207-212.

16. Kolodziejek, J. (2018). Seed germination responses to some environmental factors in the red feather (Trifolium rubens). Pakistan Journal of Botany, 50(1), 59-65.

17. Kruse, M., Strandberg, M., \& Strandberg, B. (2000). Ecological Effects of Allelopathic Plants - a Review. National Environmental Research Institute, Silkeborg, Denmark, 66 p. NERI Technical Report No. 315.

18. Mosyakin, S. L., \& Fedoronchuk, M. M. (1999). Vascular Plants of Ukraine A nomenclatural checklist. Kiev: M. G. Kholodny Institute of Botany, $345 \mathrm{p}$.

19. Mykolaychuk, V. G. (2014). Features of growth and development of plants Trifolium rubens L. (Fabaceae) of different years of vegetation in the M. M. Gryshko National botanical garden of the NAS of Ukraine. Taurian Scientific Bulletin, 88, 133-140. [In Ukrainian]. 
20. Pavlova, N. S. (1989). Fabaceaea family. In.: Vascular plants of the Soviet Far East., 4, 191-339. [In Russian].

21. Pérez, A. J., Simonet, A. M., Pecio, Ł., Kowalczyk, M., Calle, J. M., Macías, F. A., Oleszek, W., \& Stochmal, A. (2015). Triterpenoid saponins from the aerial parts of Trifolium argutum Sol. and their phytotoxic evaluation. Phytochemistry Letters, 13, 165170. https://doi.org/10.1016/j.phytol.2015.05.020

22. Rais, E. (1978). Allelopathy. Moscow: Mir, 392 p. [In Russian].

23. Sandra, C. K. Carlsen, Hans Hans A. Pedersen, Niels H. Spliid, \& Inge S. Fomsgaard. (2012). Fate in Soil of Flavonoids Released from White Glover (Trifolium repens L.) Applied and Environmental Soil Science, 13, Article ID 743413, 10. https://doi.org/10.1155/2012/743413

24. Shmidt, V. M. (1984). Mathematical Methods in Botany. Leningrad: Leningrad University Publisher, 288 p. [In Russian].
25. Simagina, N. O. (2013). Allelopathic potential of woody plants. Scientific notes of the Taurida National V. I. Vernadsky University. Series "Biology and Chemistry", 26(65), 1, 186-193. [In Russian].

26. Tamura, S., Chang, Ch-F., Suzuki, A., \& Kumai, S. (1969). Chemical studies on "clover sickness". Part I. Isolation and structural elucidation of two new isoflavonoids in red clover. Agricultural and Biological Chemistry, 33(3), 391-397.

27. Yurchak, L. D. (2005). The allelopathy in agrobiocenoses of the aromatic plants. Kyiv: Fitosotziotzentr, 411 p. [In Ukrainian].

28. Zhmud, Ye. V. (1997). Introduction of Trifolium pannonicum Jacq. to the forest-steppe of Western Siberia. Abstract of Candidate Dissertation for Biological Sciences (03.00.31 - Forestry), $20 \mathrm{p}$. [In Russian].

N. Ya. Levchyk' , A. M. Gnatiuk' , A. V. Liubinska', N. Ye. Horbenko ${ }^{2}$

${ }^{I}$ M. M. Gryshko National Botanical Garden, NAS Ukraine, Kyiv, Ukraine

${ }^{2}$ Ukrainian National Forestry University, Lviv, Ukraine

\section{THE ALLELOPATHIC ACTIVITY OF TRIFOLIUM REPENS L. AND T. RUBENS L. (FABACEAE) IN THE CONDITIONS OF THE M. M. GRYSHKO NATIONAL BOTANICAL GARDEN OF THE NATIONAL ACADEMY OF SCIENCES OF UKRAINE}

The issue of soil fatigue and chemical interaction of plants is a complex and key problem for both agriculture, as it requires consideration of crop alteration in crop rotation and soil recreation, and in phytocenology in order to assess the competitiveness of plants in natural and cultural phytocenoses. The experience of Ukrainian and world scientists of the researched topic is analyzed, which testifies to the high allelopathic activity of plants of the genus Trifolium and the formulation of the term "clover fatigue". In the course of research the authors have found that growing for a long term in one place T. rubens and T. repens plants have an impact on the surrounding plants in the biogeocenosis. The results of research on the establishment of allelopathic activity of physiologically active substances (colins) of the rhizosphere soil and extracts of the aboveground part of plants on daily seedlings of test plants are presented. The allelopathic properties of root soil and extracts of aboveground mass of plants T. rubens and T. repens were performed according to the generally accepted method of bioassays by A.M. Hrodzinskiy (1973). It is found that during the vegetation period of plants of the genus Trifolium in the root soil there is an accumulation of colins, which gives it allelopathic activity with the highest level at the end of the growing season. We have also revealed that both root secretions and extracts of $T$. rubens plants are stronger inhibitors than T. repens plants. Thus, we have concluded that regardless of the species of plants of the genus Trifolium and the growing season, the highest allelopathic activity with a depressant nature of the extracts have a concentration of 1:10, the average - at a concentration of 1:50, the lowest allelopathic activity - at a concentration of 1:100. It is established that with increasing concentrations of solutions of plants of the genus Trifolium, their inhibitory allelopathic activity increases. The strongest inhibitory effect of $7.22 \%$ was recorded in $T$. rubens plants at the end of the growing season, which indicates the accumulation of toxic biologically active compounds in the root soil. The strongest stimulating effect of $113.64 \%$ was recorded in plants of the same species in the flowering phase, which indicates a high physiological activity of plants in this period. The establishment of qualitative and quantitative content of rhizosphere soil colins and biologically active substances of the aboveground part of plants of the genus Trifolium remains relevant for the future research.

Keywords: colins; rhizosphere soil; extracts; test plants; inhibition; stimulation; stability. 